\title{
KEPUTUSAN BERKUNJUNG PADA HOTEL IBIS DI SURAKARTA
}

\author{
Nurdiansyah Kristianto, Sudarwati, Ida Aryati D.P.W \\ Fakultas Ekonomi Manajemen, Universitas Islam Batik Surakarta \\ Jl. KH. Agus Salim No. 10 Surakarta \\ Email : diansyahn435@gmail.com
}

\begin{abstract}
The aim of this research are to find out the simultaneous and partial influence between partnership, facility and brand image toward visit decision at Ibis Hotel in Surakarta. The population in this study were ibis hotel customers in Surakarta in the October-November 2019 period, totaling 209 registered members. The samples in this study were 104 respondents. Data collection techniques in this research were using observation, documentation, and questionnaires. Technical data analysis in this research were using classic assumption test, multiple linier test, $t$ test, $f$ test, the coefficients determined. The result of this study: there is simultaneous influence between partnership, facility and brand image toward visit decision at Ibis Hotel in Surakarta. There is partial influence between partnership, facility and brand image toward visit decision at Ibis Hotel in Surakarta
\end{abstract}

Key words: partnership, facility, brand image, visit decision

\section{PENDAHULUAN}

Perusahaan dalam menjalankan usahanya harus selalu mengamati perubahan perilaku konsumen sehingga dapat mengantisipasi perubahan perilaku tersebut, untuk kemudian dijadikan kajian dalam rangka memperbaiki strategi pemasarannya dan selalu dapat meningkatkan jumlah pengunjung. Industri perhotelan adalah industri jasa yang memadukan antara produk dan layanan. Kotler dan Amstrong (2004) mendefinisikan jasa sebagai aktivitas atau manfaat yang ditawarkan oleh satu pihak lain yang pada dasarnya tanpawujud dan tidak menghasilkan kepemilikan apapun. Perkembangan jumlah hotel di Surakarta yang sangat pesat, menimbulkan persaingan perhotelan di Surakarta menjadi sangat ketat.

Perhimpunan Hotel dan restoran Indonesia (PHRI) Solo dalam JawaPos mengkhawatirkan adanya persaingan yang tidak sehat seiring dengan semakin pesatnya pembangunan hotel di Solo. Sistho A selaku pengurus Bidang Humas dan Promosi (PHRI) Solo mengungkapkan "tidak menutup kemungkinan bahwa persaingan yang tidak sehat terjadi, mengingat dengan semakin banyaknya hotel yang dibangun akan terjadi ketimpangan antara demand and supply. dimana jumlah kunjungan yang tidak sebanding dengan banyaknya hotel yang ada di Solo, maraknya pembangunan hotel dikhawatirkan akan terjadi perang harga".

Banyak hal yang dapat mempengaruhi tingkat kesuksesan usaha perhotelan, salah satunya adalah bagaimana pihak hotel dapat meningkatkan keputusan kunjungan pelanggan 
dengan memperhatikan beberapa faktor antara lain partnership, fasilitas, dan brand image. Putra (dalam Gustian, dkk: 2019) menyebutkan bahwa Kemitraan adalah suatu konsep kerjasama yang memiliki kriteria seperti dilakukan lebih dari satu pihak, mempunyai kebutuhan masing- masing, namun sepakat mencapai visi dan tujuan untuk meningkatkan kapasitas.

Selain dipengaruhi oleh partnership, fasilitas juga dapat mempengaruhi keputusan berkunjung. Fasilitas adalah perlengkapan- perlengkapan fisik untuk memberikan kemudahan kepada para tamu dalam melaksanakan aktivitas - aktivitas atau kegiatan - kegiatannya, sehingga kebutuhan- kebutuhan tamu dapat terpenuhi selama tinggal dihotel ( Sulastiyono, 2006).

Brand image juga mempengaruhi keputusan berkunjung. Menurut Kotler dan Keller (2009:403) Brand Image (citra merek) adalah persepsi dan keyakinan yang dipegang oleh konsumen, seperti yang dicerminkan asosiasi yang disimpan dan tertanam dalam memori atau ingatan pelanggan, yang selalu diingat pertama kali saat mendengar slogan dan tertanam dibenak konsumennya.

Berdasarkan observasi awal yang telah dilakukan di hotel Ibis di Surakarta, terdapat beberapa kali penurunan intensitas jumlah tamu dalam beberapa bulan terakhir. Hotel Ibis termasuk kedalam wilayah yang strategis karena berada ditengah kota Surakarta. Disekeliling hotel Ibis terdapat Rumah Sakit PKU Muhammadiyah Solo, Pusat Toko Buku besar Gramedia, Bank BRI, Luwes Swalayan, dan berada di pinggir Jalan Slamet Riyadi Solo. Berdasarkan uraian diatas, kemudian timbul pemikiran bagaimana keseluruhan aspek (partnership, fasilitas, dan brand image) saling berkeseimbangan sehingga mempengaruhi dan mampu meningkatkan keputusan berkunjung pada hotel Ibis di Surakarta. Maka dari itu diperlukan penelitian yang dapat membuktikan faktor - faktor tersebut berpengaruh terhadap keputusan berkunjung pada hotel Ibis di Surakarta. Dari uraian tersebut diatas, peneliti tertarik untuk melakukan penelitian dengan judul "Keputusan berkunjung pada hotel ibis di Surakarta"

\section{TINJAUAN TEORITIS}

\section{Keputusan berkunjung}

Keputusan berkunjung merujuk pada konsep keputusan pembelian konsumen. Menurut Tjiptono (2008: 21) keputusan pembelian adalah sebuah proses dimana konsumen mengenal masalahnya, mencari informasi mengenai produk atau merek tertentu dan mengevaluasi seberapa baik masing-masing alternatif tersebut dapat memecahkan masalahnya, yang kemudian mengarah kepada keputusan pembelian.

\section{Partnership}

Kemitraan / partnership dapat dimaknai sebagai satu bentuk persekutuan antara dua belah pihak atau lebih yang membentuk suatu ikatan kerjasama atas dasar kesepakatan dan rasa saling membutuhkan dalam rangka meningkatkan kapabilitas di suatu bidang usaha tertentu atau tujuan tertentu, sehingga dapat memperoleh hasil yang lebih baik (Gustian, dkk: 2019) 


\section{Fasilitas}

Menurut Tjiptono (2015) fasilitas adalah penyediaan perlengkapan-perlengkapan fisik untuk memberi kemudahan kepada konsumen untuk melaksanakan aktivitas- aktivitas sehingga kebutuhan konsumen dapat terpenuhi.

\section{Brand image}

Menurut Kotler dan Keller (2009:403) Brand Image (citra merek) adalah Persepsi dan keyakinan yang dipegang oleh konsumen, seperti yang dicerminkan asosiasi yang disimpan dan tertanam dalam memori atau ingatan pelanggan, yang selalu diingat pertama kali saat mendengar slogan dan tertanam dibenak konsumennya.

\section{Kerangka Penelitian}

Untuk mempermudah pemahaman dan memperjelas penelitian maka dapat digambarkan suatu kerangka penelitian teoritis sebagai berikut:

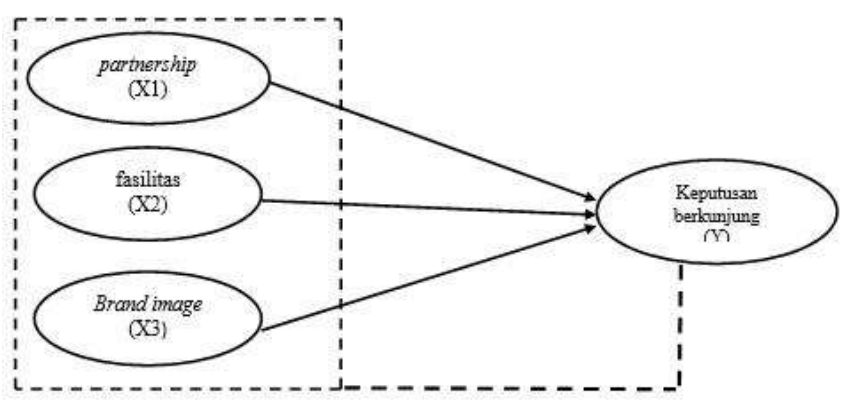

Gambar 1. Kerangka pemikiran

\section{Hipotesa}

a. H1 : Diduga partnership, fasilitas, dan brand image berpengaruh secara simultan dan dapat meningkatkan keputusan berkunjung pada hotel ibis di Surakarta.

b. H2 : Diduga partnership berpengaruh dan dapat meningkatkan keputusan berkunjung pada hotel ibis di Surakarta.

c. H3 : Diduga fasilitas berpengaruh dan dapat meningkatkan keputusan berkunjung pada hotel ibis di Surakarta.

d. H4 : Diduga brand image berpengaruh secara simultan dan dapat meningkatkan keputusan berkunjung pada hotel ibis di Surakarta.. 


\section{METODE PENELITIAN}

\section{Populasi dan Sampel}

Populasi dalam penelitian ini adalah seluruh pelanggan hotel ibis di Surakarta periode Oktober-November 2019 yang berjumlah 209 yang telah terdaftar menjadi member.. Sampel dalam penelitian ini adalah 104 responden. Teknik sampling yang digunakan dalam penelitian ini adalah probability sampling, adapun teknik problability sampling yang digunakan adalah simple random sampling.

\section{Model dan teknis Analisis}

Pendekatan penelitian yang digunakan dalam penelitian ini adalah menggunakan analisis deskriptif dengan pendekatan kuantitatif. Untuk menguji pengaruh variable independen terhadap variable dependen baik secaraparsial maupun simultan menggunakan analisis regresi linear berganda. Berikut bentuk persamaan regresi dalam penelitian ini: ((Ghozali (2009: 17))

$$
\mathrm{Y}=\mathrm{a}+b_{1} \quad X_{1}+b_{2} X_{2}+\mathrm{b}_{2} \mathrm{X}_{3}+\mathrm{e}
$$

Keterangan :

$$
\begin{aligned}
& \text { Y = keputusan berkunjung a = Konstanta } \\
& \begin{array}{l}
\text { bn } \\
x_{1}
\end{array} \quad \begin{array}{l}
\text { Koefisien regresi variabel bebas ke-n } \\
=\text { Variabel partnership }
\end{array} \\
& \begin{array}{ll}
x_{2} & =\text { Variabel fasilitas } \\
\mathrm{x} 3 & =\text { Variabel brand image } \\
\mathrm{e} & =\text { Variabel pengganggu (error) }
\end{array}
\end{aligned}
$$

Selanjutnya dilakukan uji F, uji T, dan koefisien determinasi.

\section{Pengujian Hipotesis}

Untuk menguji hipotesis nomer 1 peneliti menggunakan uji F, Uji F digunakan untuk menguji koefisien regresi secara simultan atau bersama - sama antara variabel independen dengan variable dependen. Penilaian dengan melihat nilai Fhitung. Jika fhitung < nilai F table, maka Hipotesis penelitian diterima. Dalam penelitian ini, hasil uji $\mathrm{F}$ menerangkan sejauh mana pengaruh bersama - sama partnership, fasilitas, dan brand image terhadap keputusan berkunjung. Untuk melihat besarnya keputusan berkunjung pelanggan dapat dilihat dari besarnya koefisien determinasi. Kemudian nilai $t$ hitung dilakukan untuk melihat pengaruh secara parsial antara variable independen terhadap variable dependen. Penilaian dilihat dari nilai thitung. Jika nilai thitung lebih besar dari ttabel, maka hipotesis diterima. 


\section{HASIL PENELITIAN DAN PEMBAHASAN}

Hasil perhitungan analisis regresi berganda dengan menggunakan SPSS 25 disajikan dalam table berikut:

\begin{tabular}{|c|c|c|c|c|c|}
\hline \multirow[b]{2}{*}{ Model } & \multicolumn{2}{|c|}{$\begin{array}{l}\text { Unstandardize } \\
\text { d Coefficients }\end{array}$} & \multirow{2}{*}{$\begin{array}{c}\begin{array}{c}\text { Standa } \\
\text { rdized } \\
\text { Coeffici } \\
\text { ents }\end{array} \\
\text { Beta }\end{array}$} & \multirow[b]{2}{*}{$\mathrm{t}$} & \multirow[b]{2}{*}{ Sig. } \\
\hline & $B$ & $\begin{array}{l}\text { Std. } \\
\text { Error }\end{array}$ & & & \\
\hline (Constant) & .247 & 1.250 & & .198 & .844 \\
\hline Partnership & .308 & .053 & .328 & 5.778 & .000 \\
\hline Fasilitas & .181 & .053 & .205 & 3.409 & .001 \\
\hline Brand image & .548 & .062 & .552 & 8.856 & .000 \\
\hline
\end{tabular}

a. Dependent Variable: keputusan berkunjung

Fhitung $=85,541 \quad \mathrm{n}=104$

Ftabel $=2,69 \quad$ sig $=0,000$

Ttabel $=1,98 \quad \mathrm{R}$ square $=0,720$

Sesuai dengan hasil analisis regresi linier berganda sebagai berikut:

$Y=0,247+0,308 X 1+0,181 X 2+0,548 X 3$

Hasil tersebut menunjukkan bahwa partnership, fasilitas, dan brand image berpengaruh sigifikan terhadap variabel keputusan berkunjung. Sedangkan dari hasil uji $\mathrm{t}$ dapat diperoleh variabel partnership dengan nilai thitung $=5,778>$ tabel $=1,98$, maka Ho ditolak sehingga ada pengaruh yang signifikan partnership terhadap keputusan berkunjung pada hotel ibis di Surakarta, diperoleh variabel fasilitas dengan nilai thitung = 3,409 $>$ ttabel $=1,98$, maka Ho ditolak sehingga ada pengaruh yang signifikan fasilitas terhadap keputusan berkunjung pada hotel ibis di Surakarta, variabel brand image dengan nilai thitung $=8,856>$ ttabel $=1,98$, maka Ho ditolak sehingga ada pengaruh yang signifikan brand image terhadap keputusan berkunjung pada hotel ibis di Surakarta. Hasil perhitungan uji $\mathrm{F}$ dapat diperoleh diperoleh nilai Fhitung $=85,541>$ Ftabel $=2,69$, maka Ho ditolak sehingga secara bersama-sama ada pengaruh yang signifikan partnership, fasilitas, dan brand image terhadap keputusan berkunjung pada hotel ibis di Surakarta.

\section{KESIMPULAN DAN SARAN}

\section{Kesimpulan}

1) Partnership (X1), fasilitas (X2), dan brand image (X3) berpengaruh secara simultan terhadap keputusan berkunjung pada hotel ibis di Surakarta (Y) 
2) Ada pengaruh signifikan partnership terhadap keputusan berkunjung pada hotel ibis di Surakarta.

3) Ada pengaruh signifikan fasilitass terhadap keputusan berkunjung pada hotel ibis di Surakarta.

4) Ada pengaruh signifikan brand image terhadap keputusan berkunjung pada hotel ibis di Surakarta

\section{Saran}

Berdasarkan analisis dan kesimpulan, maka dapat disampaikan saran-saran sebagai berikut:

5) Manajemen Hotel Ibis dalam usaha meningkatkan jumlah pengunjung, maka seyogyanya memperhatikan faktor- faktor yang telah diteliti (partnership, fasilitas, dan brand image)..

6) Faktor-faktor dalam model tersebut perlu ditingkatkan lagi oleh manajemen hotel Ibis, karena hasil analisis data menunjukkan adanya pengaruh yang signifikan antara partnership, fasilitas, dan brand image terhadap keputusan berkunjung pada hotel ibis di Surakarta.

7) Bagi peneliti lain pada penelitian selanjutnya dalam meningkatkan keputusan berkunjung pelanggan disarankan untuk mencari dan menerapkan faktor - faktor lain yang belum digunakan dalam model guna penelitian yang lebih mendalam seperti promosi dan lokasi.

\section{DAFTAR PUSTAKA}

Ghozali , I. 2009. Aplikasi Analisis Multivariate Dengan Program Ibm Spss 20. Semarang: Badan Penerbit- Universitas Diponegoro

Gustian Riadi Saputra, Dkk. 2019. Kemitraan Pengelolaan Pariwisata Dalam Meningkatkan Pendapatan Asli Daerah Kabupaten Tasikmalaya Tahun 2017 (Studi Kasus Objek Wisata Gunung Galunggung Kabupaten Tasikmalaya). Jurnal Ilmu Pemerintahan. Volume 03 Nomor 02:298-341

Kotler dan Amstrong. 2004. Prinsip-prinsip Pemsaran . Jakarta: Erlangga

Kotler .Keller. 2009. Manajemen Pemasaran, Edisi Ke 13. Jilid 1. Jakarta : Erlangga

Sulastiyono, Agus. 2006. Manajemen Penyelenggaraan Hotel. Bandung: Cv. Alfabeta

Tjiptono , Fandy. 2015. Brand Management \& Strategy. Yogyakarta : Andi. 